\title{
Crossing the Boundary: From Experimental Psychology to Ethnomusicology ${ }^{[1]}$
}

\author{
JOHN BAILY \\ Head of the Afghanistan Music Unit, \\ Goldsmiths, University of London
}

\begin{abstract}
In attempting to understand the difficulties raised by Judith Becker's experiences with crossing boundaries between disciplines, the author is prompted to examine how he successfully negotiated the intellectual journey from psychology to musicology in the course of his academic career. Apart from taking advantage of unique opportunities offered, and fortuitous developments in the field of music cognition, he attributes his success to having doctoral degrees in both psychology and musicology, the second the result of being awarded a Social Science Research Council Conversion Fellowship in 1975 specifically intended to train natural scientists to become social scientists. Thanks are offered to the SSRC committee that took the decision to establish this training scheme.
\end{abstract}

Submitted 2009 May 15; accepted 2009 May 27.

KEYWORDS: psychology, musicology, ethnomusicology, anthropology, research

BILL Thompson was kind enough to invite me to write a short piece in response to Judith Becker's "Crossing Boundaries: An Introductory Essay". I do not wish to comment on the specific difficulties Professor Becker has encountered in having her innovative work published, but I can say something about my own progression from experimental psychology to ethnomusicology in the course of my academic career. This journey has been made via social anthropology, with a side-step into ethnographic film making.

I had the good fortune to gain entrance to Oxford University in 1962, where I read Psychology and Physiology. I had two outstanding teachers in the celebrated Oxford tutorial system, NS Sutherland, who was soon to set up the Laboratory for Experimental Psychology at Sussex University, where I later studied for my $\mathrm{PhD}$ in experimental psychology, and Nicholas Macintosh, later Professor of Neuropsychology at Cambridge University. While at Oxford, I became very interested in human spatial orientation and the phenomenon of prism adaptation, a subject that was quite important at the time, especially with the pioneering work of Richard Held at MIT. Sutherland, who had just spent a sabbatical term at MIT, introduced me to this research. Amongst other things, Held predicted on the basis of his experiments that in the gravity-free situation the human sensori-motor system would become progressively discoordinated, a prediction that subsequent space travel showed was clearly wrong. Nevertheless, the question of human sensori-motor coordination in zero-gravity remains, for obvious reasons, a matter of great interest and importance.

Visiting Australia in 1966 before starting my PhD work on prism adaptation under the supervision of Sutherland at Sussex, in what these days would be termed a 'gap year', I met George Singer, then a lecturer in psychology at Sydney University. George Singer and his colleague Ross Day had carried out a number of studies of adaptation to rotations of the visual field, and George employed me as his research assistant for several months, when we ran an experiment together published under the names of Baily and Singer in the Australian Journal of Psychology. I doubt that this paper made much of an impact on the field of prism adaptation but it looked good on my $\mathrm{CV}$ when I became a research student.

At Sussex I had a lot of fun devising an elaborate apparatus for measuring eye-hand coordination and for pointing with passive arm movements (Baily, 1972a\&b). And in about 1968 I discovered Bruno Nettl's Theory and Method in Ethnomusicology in the Sussex University library, placed there by some enlightened librarian. From this I was directed to Mantle Hood's paper "The Challenge of Bi-musicality", published in the journal Ethnomusicology, which argued that training in basic musicianship is fundamental to any kind of musical scholarship, and that the student of exotic music should learn to perform it. While at Sussex I also read up on the psychology of music, though there was not much published on this topic at the 
time. Having completed my PhD in 1970 with a thesis entitled Prism Adaptation and Motor Control, I traveled again through the Middle East and South Asia, now equipped with a cassette tape recorder. I made my first recordings of music in Afghanistan and started to think seriously about the long-necked Afghan lutes I encountered, notably the dutâr, the tanbur and dambura. From the point of view of a guitar player (which I was) these instruments were extremely interesting, both in terms of their timbres and the musical complexity that was possible from seemingly simple physical resources. I then spent seven months in Nepal, where I studied the Indian tabla drums (in my enthusiasm I had the temerity to publish my lessons as Krishna Govinda's Rudiments of Tabla Playing) and the basics of Indian rag. This knowledge of Indian music proved of great benefit when working later in Afghanistan.

On the basis of these experiences, I determined that ethnomusicological research was the kind of academic work I wished to pursue, and putting together music and psychology seemed the way to do this. In 1972 I made contact with John Blacking, newly appointed to the Chair of Social Anthropology at The Queen's University of Belfast, and already recognized as a dynamic new voice on the ethnomusicological scene, especially in the US. I have written extensively about my early encounters with Blacking elsewhere (Baily 1994), and there is no need to repeat them here. In John Blacking I found somebody who believed in the contribution that psychology could make to ethnomusicology, with its programme to "identify all processes that are relevant to an explanation of musical sound" (Blacking, 1973:17). Blacking had interesting ideas about the interface between the human body and a musical instrument, but lacked the technical knowledge of experimental psychology to analyze more systematically what was going on at the interface.

In September 1972 we submitted our joint application to the Social Science Research Council for a project entitled "A cross-cultural study of music skills". It is worth reproducing the introductory statement to our proposed investigation because it shows a good deal about the very "scientific" and highly structuralist approach we were adopting for the study of what we called "field skills":

Man's ability to use his hands in a skilful manner to manipulate the environment and to engage in complex operations is one of his most important capacities, and has been a crucial factor in his physical and cultural evolution. This important area of human behaviour has received a good deal of attention from experimental psychologists and others, who have employed a variety of abstract laboratory tasks to isolate and investigate many of the component processes underlying skilled performance. Man, however, is not a laboratory animal, and the laboratory approach hardly does justice to the complexity and richness of the skilled behaviour which he exhibits in his normal everyday life. We will term such everyday skilled activities field skills.

There are two main features of a field skill. Firstly, at the behaviourial level, the skill consists of a basic set of component actions. These make up the motor vocabulary of the skill. The range of possible component actions available to man is large, but the vocabulary of a particular skill consists of a rather limited set drawn from this. Through grouping and sequential ordering, these component actions are elaborated into the motor patterns which are characteristic of the skill. In other words, the component actions of a particular skill are organised into a certain type of structure, which is determined by a set of structural rules. The motor patterns characteristic of the skill are, in a sense, generated from these structural rules. The isolation and definition of its structural rules should be one of the main objectives in the analysis of a field skill.

The second feature of a field skill is that there are a variety of social and cultural factors which impinge upon its performance. These factors determine not only when and where the skilled activity is performed, but how it is performed. They have a profound effect in shaping the motor patterns which may be observed at the behaviourial level. For this reason, the structure of a field skill cannot be fully appreciated without considering its social and cultural environment. The structural rules underlying a field skill will, to some extent, reflect constraints imposed by gross anatomy, neural wiring within the sensorimotor system, and the psychological processes underlying skilled performance, but they will also reflect social and cultural constraints. It is evident that even such basic activities as walking, standing, sitting and reaching are influenced by social and cultural factors. This influence is more obvious when we consider patterns of movement such as gestures 
and facial expressions which serve a communicative function. It is difficult to discover what man's "natural" patterns of movement are until these social and cultural influences on body movement and posture have been estimated.

At present, we can only guess at the impact of social and cultural processes on complex manipulative skills. This problem calls for a cross-cultural study of elaborate and highly structured field skills, in which we try to relate inter-cultural variations in skilled performance with processes in the social/cultural environments. This is the general orientation of the research proposed here (Blacking and Baily, 1973:9-10).

The grant application went on to argue that music provides a very profitable area for the study of the organization of motor patterns in skilled manipulative behavior, and outlined one of the key elements of our approach, which was to look at the relationships between (a) the spatial layout (the morphology) of the instrument, (b) the organization of motor patterns in the playing technique, and (c) the generative rules which govern the structure of the music produced. Eventually our proposal was accepted by the SSRC, I was awarded a post-doctoral research fellowship, and in 1973 I began my first year of fieldwork in the city of Herat, in western Afghanistan. I was accompanied by my wife Veronica Doubleday, who was to become a very important part of my later research project, enabling us to work on "both sides of the curtain", i.e. in the largely separate worlds of men's and women's music making.

The Afghan instrument selected for this research, the Herati dutâr, had undergone a dramatic transformation between 1950 and 1965, changing from a two stringed instrument of rural amateur music making, to a much larger 14 stringed instrument now played by urban professionals. My task was to investigate these changes in terms of the three parameters mentioned above: morphology, movement, and music. My research was systematic, if not scientific. Having done some preliminary work and learning to play the dutâr a bit myself, I set up a "Main Sample" of 15 dutâr players, consisting of 5 groups with three men in each group. Groups (1) and (2) were learners and performers of the 3 stringed dutâr; Groups (3) and (4) were learners and performers of the 14 stringed dutâr; while Group (5) consisted of outstanding players of the 14 stringed dutâr. I identified (perhaps constructed would be a better term) a standard repertoire of 5 dutâr tunes, which were recorded from all 15 players, and their hand movements were also filmed for movement analysis. Two men from each group also submitted to lengthy recorded interviews exploring their social background, how they had learned to play, and some of their ideas about the music and how they played it. In the analysis of the data, back in Belfast, the long necked dutâr was compared with another Afghan instrument, the rubâb, which I also studied in this period, though it was not part of the original research proposal. This allowed a very revealing comparison to be made between two kinds of spatial layout of note positions: the linear array of the dutâr, on which only the top string is actually fingered, and the tiered array of the rubâb, with its three melody strings. This comparison showed how the different 'musics' traditionally played on these two instruments were adapted to the morphologies of the two instruments. Learning to play these instruments myself was an important source of insight into these matters. While this might have seemed unduly subjective, I took comfort from the knowledge that some of Helmhotlz's discoveries were based on his own observations, including some of the basic facts about prism adaptation.

While working in Belfast on the dutâr/rubâb material, the opportunity arose to apply for a SSRC Conversion Fellowship, a new scheme intended to turn natural scientists into social scientists. The intentions behind this scheme are not available to me now, but there must have been the notion that the UK was short of social scientists and here was a way to recruit more of them. Experimental psychology was accepted as a natural science, and I received funding for three years; the first year in Belfast attending undergraduate lectures in social anthropology and the centrally important weekly research seminars, then a second year of fieldwork on the anthropology of music in Herat, while for the third year I moved to St. Antony's College, Oxford, where I was attached to its Middle East Centre. Thinking about it now, I realize that this Conversion Fellowship was the crucial step that allowed me to cross the boundary from natural science to the humanities, and I thank whichever committee it was that took the decision to establish this training scheme.

In 1978 I was appointed Lecturer in Social Anthropology at The Queen's University of Belfast, to coordinate and teach the newly established MA in Ethnomusicology, and a year later my job was converted to Lecturer in Ethnomusicology; Blacking was keen to have a post specifically dedicated to this strand of the Department's work. I learned much of what I know about my subject through teaching courses like Theory and Method in Ethnomusicology, Anthropology of Music, Ethnography of World Music and Dance, and Music of Afghanistan as a special area of study. In 1983 I was back in the Laboratory of Experimental 
Psychology at Sussex for a sabbatical year, where my work received strong encouragement from several of my psychology colleagues with a keen interest in music, including Phil Johnson-Laird, Christopher LonguettHiggins, and Chris Darwin. It was at this point that I wrote my best-known paper on music structure and human movement (Baily, 1985). I also started work on the idea of motor grammars underlying musical performance, having found an excellent example in the right hand technique for playing the Afghan rubâb (Baily, 1987).

In 1984 the Royal Anthropological Institute advertised two one-year training fellowships in anthropological film making, funded by the Leverhulme Trust and tenable at the National Film and Television School (NFTS). I was one of many who applied: the three films I had edited in Belfast about Herat, using footage I had shot during my fieldwork there in the 1970s, no doubt led to my being offered one of the two fellowships. In what some of my colleagues regarded as an act of folly, I gave up my tenured position in Belfast to take up this new opportunity. The idea of the scheme was not to convert anthropologists (and ethnomusicologists) into professional film makers, but to encourage the use of film in the teaching of anthropology. My fellow anthropologist/trainee was Dr Paul Henley, who became Director of the Granada Centre for Visual Anthropology at Manchester University in 1987. I made two films in this period: Amir: An Afghan refugee musician's life in Peshawar, Pakistan and Lessons from Gulam; Asian music in Bradford (both distributed by the Royal Anthropological Institute in the UK and Documentary Educational Resources in the US).

After film school I spent two years as a Visiting Research Fellow in the School of African and Asian Studies at Sussex University. This gave me the chance to catch up with my more conventional academic work, allowing me to finish my ethnographic monograph Music of Afghanistan: Professional musicians in the city of Herat, to complete my second $\mathrm{PhD}$ thesis in Social Anthropology (Ethnomusicology) at QUB, and to think further about anthropological and psychological approaches to the study of music (Baily, 1988). In 1988 I was appointed Associate Professor in the Center for Ethnomusicology at Columbia University, New York, where I learned a lot from working with its Director, Dieter Christensen. In 1990 I returned to the UK to take up a Senior Lectureship in Ethnomusicology at Goldsmiths, where I am now Professor Emeritus and Head of the Afghanistan Music Unit. In the last 20 years I have maintained my interest in music cognition with a series of publications (Baily, 1991; 1992; 1995; 1996; 1997) and extended some of my ideas about the ergonomics of performance to playing the guitar (Baily and Driver, 1992). I have developed my ideas about the importance of learning to perform as a research technique in ethnomusicology (Baily, 2008), and continuing the RAI film project, maintained my commitment to the movie camera as a research tool and film as a form of ethnomusicological text (Baily, in press). At the time of writing, I hold a Leverhulme Emeritus Fellowship to write a monograph bringing together my many field trips to sites of Afghan settlement in Pakistan, Iran, US and Europe, and, after 2001, to Afghanistan. In March and April 2009 I was a Visiting Research Fellow at Monash University, Melbourne, conducting research on Afghan music in Australia, part of my long-term project on the globalization of Afghanistan's music.

Reflecting on how I was able to cross the boundary between experimental psychology and ethnomusicology, I make the following observations.

1. My undergraduate and postgraduate education in experimental psychology was of crucial importance; it provided a very rigorous training in the conduct of empirical research, with the formulation of hypotheses, experimental design, the use of statistics to measure probability, and in logical thinking. It seems easier to cross from science to humanities than the other way round.

2. The emergent interest in the psychology of music, music perception, and musical cognition in the 1970s and 1980s was a great advantage.

3. I made the transition from experimental psychology to ethnomusicology quite early in my career. My Conversion Fellowship, which is the point when I truly crossed the border between the two, began in 1975, when I was 32 years of age.

4. Ethnomusicology was a very young subject when I went into it. No training was available in the UK at the time. British ethnomusicologists like Frank Denyer and Neil Sorrell had trained in the US. The door was open in the UK for scholars to come into ethnomusicology from various backgrounds.

5. Having PhDs in both experimental psychology (1970) and ethnomusicology (1988) gave the transition retrospective credibility. 
6. Being able to perform the music you are studying to a high level of competence is also helpful in being accepted by the community of musicologists.

7. There was no "master plan"; I responded to opportunities as they arose and I was ready to take risks. Moreover, I was incredibly lucky in my mentors: Sutherland, Mackintosh, Blacking, and Christensen.

Looking at my own work as an ethnomusicologist, I realize that deep down I remain a scientist, for I still think along scientific lines. However, I do not call myself a scientist and unlike some of my European colleagues, I do not describe ethnomusicology as a scientific discipline. I think of my work as systematic, and theory-orientated. When I started teaching the history of ethnomusicology, I took comfort from the fact that ethnomusicology's precursor, comparative musicology, began life in the Institute for Psychology in Berlin, under the leadership of Carl Stumpf, one of the founding fathers of experimental psychology. Many of the issues addressed by the Berlin School were connected to the psychology of music and the place of music in the human mind. In her introductory essay Judith Becker mentions three specific problems for ethnomusicologists wanting to applying empirical methods to their work: research in music cognition has overwhelmingly dealt with Western art music; empiricism's concern with experimental minutiae; lack of familiarity with statistics. I sympathise. My work with Blacking specifically offered the critique that 'Practitioners of the psychology of music have not only tended to use for their research those kinds of music that are highly valued in Western society but also implicitly adopted certain views about the nature of music put forward by western musicians, musicologists, and teachers of music...' (Baily 1985: 238). A strength of Blacking's early insights into the body/instrument interface what that they came from the study of African instrument. I agree with Becker that the empirical method is unsatisfactory in the way that it focuses on small details. Rerunning the experiment with slight changes to the parameters might come up with a very different result. The problem with the use of statistics as measures of probability is connected to that empirical methodology. In my own work I applied what I knew about psychology in a non-empirical manner to understand more about processes of musical cognition.

\section{NOTES}

[1] This paper was written while the author was a Visiting Fellow at Monash University, jointly in the School of Music - Conservatorium, and the Monash Asia Institute.

\section{REFERENCES}

Baily, J.S., \& Singer G. (1967). "Behavioural compensation through false information feedback and transformed visual input", Australian Journal of Psychology, 19:49-53.

Baily, J.S., (1972a). "Adaptation to prisms: Do proprioceptive changes mediate adapted behavior with ballistic arm movements?", Quarterly Journal of Experimental Psychology, 24:8-20.

Baily, J.S., (1972b). "Arm-body adaptation with passive arm movements", Perception and Psychophysics, 12:39-44.

Baily, J., (1974). Krishna Govinda's Rudiments of Tabla Playing. Brighton: Unicorn Books. With accompanying audio cassette. 89 pages.

Baily, J., (1977). "Movement patterns in playing the Herati dutâr", in John Blacking (ed), The Anthropology of the Body, London: Academic Press, 275-330.

Baily, J., (1985). "Music structure and human movement", in Peter Howell, Ian Cross and Robert West (eds)., Musical Structure and Cognition, London: Academic Press, 237-258. 
Baily, J., (1987). "Principes d'improvisation rythmique dans le jeu du rubâb d'Afghanistan", in L'Improvisation dans les musiques de tradition orale, Bernard Lortat-Jacob (ed), Paris: SELAF, 175-188.

Baily, J., (1988). Music of Afghanistan: Professional musicians in the city of Herat. Cambridge: Cambridge University Press. With accompanying audio cassette. 183 pages.

Baily, J., \& Doubleday, V., (1988). "Modeles d'impregnation musicale en Afghanistan", in Laurent Aubert (ed), Cahiers de musiques traditionelles 1: De bouche a oreille, Geneva: Ateliers d'ethnomusicologie, 112-124. English version published 1989 as "Patterns of musical enculturation in Afghanistan", in Frank Wilson and Franz Roehmann (eds), Music and Child Development: Proceedings of the 1987 Denver Conference. St. Louis: MMB Music, 88-99.

Baily, J., (1988). "Anthropological and psychological approaches to the study of music theory and musical cognition", Yearbook for Traditional Music, 20:114-124.

Baily, J., (1989). "The role of a motor grammar in the performance of music", in Frank Wilson and Franz Roehmann (eds), Music and Child Development: Proceedings of the 1987 Denver Conference. St. Louis: MMB Music, 202-213.

Baily, J., (1991). "Some cognitive aspects of motor planning in musical performance", Psychologica Belgica, XXXI(2):147-162.

Baily, J., \& Driver, P., (1992). "Spatio-motor thinking in playing folk blues guitar", World of Music, special issue on Ethnomusicology and Music Cognition, guest editor Ellen Koskoff , 34(3):57-71.

Baily, J., (1992). "Music Performance, Motor Structure, and Cognitive Models", in Max Peter Baumann, Artur Simon and Ulrich Wegner (eds), European Studies in Ethnomusicology: Historical Developments and Recent Trends. . Berlin: International Institute for Comparative Music Studies and Documentation, 142-158.

Baily, J., (1994). John Blacking: Dialogue with the Ancestors, The John Blacking Memorial Lecture, European Seminar in Ethnomusicology, Geneva, 1991. London: Goldsmiths College. 20 pages.

Baily, J., (1995). "Music and the Body", World of Music. Special Issue entitled "Working with Blacking", guest editor John Baily.

Baily, J., (1996). "Using Tests of Sound Perception in Fieldwork", Yearbook for Traditional Music, 28:147173.

Baily, J., (1997). "Afghan perceptions of birdsong", World of Music, special issue on Cultural Concepts of Hearing and Listening, 39(2): 51-59.

Baily, J., (2001). "L'interaction homme/instrument. Vers une conceptualisation", in Laurent Aubert (ed) Cahiers de musiques traditionelles 14: Le geste musical. Geneva: Ateliers d'ethnomusicologie, 125-141.

Baily, J., (2006). "John Blacking and the 'human/musical instrument interface': two plucked lutes from Afghanistan", in Suzel Ana Reily (ed) The Musical Human. Rethinking John Blacking's Ethnomusicology in the Twenty-First Century. Aldershot: Ashgate, pp. 107-124.

Baily, J., (2008). "Ethnomusicology, Intermusability, and Performance Practice", in Henry Stobart (ed) The New (Ethno)musicologies. Scarecrow, pp. 121-138.

Baily, J., (in press). "The art of the 'fieldwork movie': 35 years of making ethnomusicological films", Ethnomusicology Forum, special issue on music and the moving image.

Blacking, J., (1973). How Musical is Man? Seattle: University of Washington Press. With accompanying audio tape. 
Doubleday, V., \& Baily J., (1995). "Patterns of musical development among children in Afghanistan", in Elizabeth Warnock Fernea (ed), Children in the Muslim Middle East Today. Austin: Texas University Press, 431-446. 